\title{
Reynolds shear-stress and velocity: Positive biological response of neotropical fishes to hydraulic parameters in a vertical slot fishway
}

\author{
Bernardo Alan de Freitas Duarte, Isabella Cristina Resende Ramos and \\ Hersília de Andrade e Santos
}

The barriers created by dams can cause negative impacts to aquatic communities, and migratory fish species are directly affected. Fishways have been developed to allow the upstream passage of fishes through dams. In Brazil, after the implementation of environmental laws, these structures have been built based on European and American fishway designs. Studies have shown selectivity for different neotropical fishes in some Brazilian fishways, and the main challenge has been to promote upstream passage of a large number of diverse fish species. The patterns of flow circulation within the fish ladder may explain fish selectivity although few studies detail the fish response to hydraulic characteristics of fish ladder flow. This paper presents a laboratory study, where a vertical slot fishway was built in a hydraulic flume and the behavior of two neotropical fish species (Leporinus reinhardti and Pimelodus maculatus) were analyzed. The structure of flow was expressed in terms of mean velocity, Reynolds shear-stress and velocity fluctuation fields. The individuals of Leporinus reinhardti had higher passage success than Pimelodus maculatus in the laboratory flume. Both species preferred areas of low to zero Reynolds shear-stress values. In addition, different preferences were observed for these species concerning the horizontal components of velocity fluctuation.

Interrupções em rios, como as causadas por barragens, provocam impactos negativos sobre as comunidades aquáticas e as espécies migratórias de peixes são diretamente afetadas. A fim de permitir a passagem de peixes, mecanismos de transposição são construídos junto a barramentos. No Brasil, após a implantação de leis ambientais, estas estruturas passaram a ser amplamente construídas e foram baseadas em projetos desenvolvidos na Europa e na América do Norte. Análises de mecanismos já construídos têm mostrado grande seletividade para espécies neotropicais e as demandas da diversa fauna de peixes neotropical são apresentadas como principal desafio ao projeto de passagens para peixes. Os padrões de escoamento dentro de escadas para peixes podem explicar a seletividade destes mecanismos, mas poucos estudos detalham a resposta dos peixes às características hidráulicas encontradas dentro das escadas. Este estudo apresenta uma análise realizada em um laboratório onde foi construída uma escada do tipo ranhura vertical e analisados os comportamentos de duas espécies neotropicais (Leporinus reinhardti e Pimelodus maculatus). O escoamento foi estudado considerando os campos de velocidade média, tensão cisalhante de Reynolds e flutuações de velocidades. Os indivíduos da espécie Leporinus reinhardti apresentaram maior sucesso de passagem do que os da espécie Pimelodus maculatus. Ambas as espécies preferiram áreas de tensão de Reynolds igual a zero. Além disso, diferentes preferências foram observadas para cada espécie em relação às componentes horizontais da flutuação da velocidade.

Key words: Leporinus reinhardti, Neotropical fish, Pimelodus maculatus, Velocity, Vertical slot.

\section{Introduction}

In the last 50 years the growth of energy demands has encouraged the construction of new dams in Brazil. Providing fish passage at dams is critical to preserve the distribution and fitness of diadromous and potamodromous species worldwide (Lucas \& Baras, 2001; Roscoe \& Hinch 2010). After implementation of environmental laws in some Brazilian states, fishways have been widely constructed (Viana et al., 2009). The principal aim of these fishways was to allow the upstream passage of migratory fish, which are a small fraction of the total fish species in South America (Petrere Jr., 1985; Godinho $\&$ Godinho, 1994) although they have great value for professional fishing (Godinho, 1993).

Upstream fish passage through dams can be provided by several types of fishways: nature-like bypass channels, fish ladders, fish lifts, fish locks or collection, and transportation facilities (Larinier \& Marmulla, 2003). An upstream fishway allows fish species to access river reaches which were previously inaccessible because of dams. Fish ladders have

Departamento de Engenharia Civil, Centro Federal de Educação Tecnológica de Minas Gerais, Câmpus II. Avenida Amazonas 7675, Nova Gameleira, 30510-000 Belo Horizonte, MG, Brazil. be.duarte@hotmail.com (BAFD); hsantos@civil.cefetmg.br (HAS) 
been the most common fish passage type constructed throughout the world (Yagci, 2010).

The challenge for building effective fishways is related to the lack of information about the demands and preferences of local fish species (Silva et al., 2009). Besides, knowledge of their swimming performance and behavior are required for design of fishways (Northcote, 1998).

One of the most widely used fish ladder in Brazil is the vertical slot model. It consists of a flume where the baffles installed at regular intervals create a series of pools. The amount of drop between the pools, which determines the maximum velocity in the jet, is straightforwardly defined by the swimming ability of the target species (Tarrade et al., 2011). A number of studies have determined the flow circulation patterns and characteristics of this fishway (Wu et al., 1999; Larinier \& Marmulla, 2003; Viana et al., 2009; Tarrade et al., 2011). However, the behavior of fish species within fish ladders is not yet well known (Silva et al., 2010).

The presence of water moving around the fish determines the action of many forces on its body, such as buoyancy. The water movements generate more forces, e.g. shear force and drag. Fish react to this force by avoiding some areas and preferring others. There are many hydraulic parameters which provide information about the forces around a fish body, such as hydraulic strain, turbulence and tensors components (Enders et al., 2003, Goodwin et al., 2006). In rotational flow within a fish ladder, the shear is particularly important; it appears when two parallel layers of water masses have opposite or parallel forces due to their velocities (Silva et al., 2010). Experiments in laboratories allow to create controlled flow in channels and to obtain accurate measurements of hydraulic parameters. Then, when they are also used to analyze fish behavior, information about fish preference can be obtained in the best way.

The aim of this study was to understand the influence of three hydraulic parameters, namely Reynolds shear-stress, velocity fluctuation and mean velocity, on two neotropical fish species within a vertical slot fish ladder. A vertical slot model was built in a laboratory flume and experiments of two different species (Leporinus reinhardti and Pimelodus maculatus) were conducted. This study allowed the determination of the effectiveness of the vertical slot fish ladder for two different neotropical species having different physical and behavior characteristics.

\section{Material and Methods}

This study was conducted in a hydraulic flume installed at the Hydraulic Laboratory of CEFET-MG (Centro Federal de Educação Tecnológica de Minas Gerais). The flume was 7.00 $\mathrm{m}$ long, $0.87 \mathrm{~m}$ wide and $1.00 \mathrm{~m}$ high; it was built in concrete and the flow was generated by a pump which assures steady flow in the recirculating water system. The bed slope of the vertical slot fishway was $4.5 \%$, which is a common slope in Brazilian fish ladders.
For model scale, the design criteria proposed by model number 1 in Rajaratnam et al. (1986) was applied. The width of the baffle slot $\left(b_{o}\right)$ was 0.11 meter and the length of the pool between baffles was 1.08 meter. The flume was divided into 3 pools. The upstream pool was numbered as pool 1 and the downstream pool was numbered as pool 3 (Fig. 1).

A flow probe used (Brand Global Water) provided only the mean and maximum velocity readings with accuracy of $0.01 \mathrm{~m} / \mathrm{s}$, i.e. it did not inform instantaneous velocity measurements. The water velocity probe consisted of a protected water displacement sensor coupled with an expandable probe handle ending in a digital readout display. The water velocity computer received an electrical signal from the propeller, amplified the signal and converted the reading to meters per second (Global Water Instrumentation, 2011).

The flow probe was placed at different horizontal levels parallel to the bottom of the flume. Velocity fields were obtained for horizontal planes from $0.10 \mathrm{~m}$ and $0.20 \mathrm{~m}$ above the flume bottom. The measurement points were distributed in the second pool by a mesh of 62 cells (the measurements were taken in the center of each cell). For each point, the $\mathrm{X}$ and $\mathrm{Y}$ components of mean $(\bar{u}, \bar{v})$ and maximum velocity $\left(u_{\max }, v_{\max }\right)$ were collected. The measurements took 2 minutes at each point, which corresponded to about 80 velocities records.

The water velocity measurements procedure consisted on 2 steps: First, the propeller probe was placed in one direction ( $\mathrm{x}$ axis) and $\mathrm{X}$ velocity components were measured. Then the probe was turned 90 degrees and in another direction (y axis) and $\mathrm{Y}$ velocity components were measured.

Only the horizontal component of Reynolds shear-stress was calculated, which was shown as the more significant factor for the behavior of an European fish species (Silva et al. 2010). The importance of this component is related to the bidirectional movement of water velocity fields in a vertical slot fish ladder for slope close to 5\% (Wu et al., 1999), due the absence of significant vertical forces.

The local velocity in a turbulent region can be decomposed into a temporal mean value $(\bar{u})$ and a component that represents the velocity fluctuation $\left(u^{\prime}\right)$ about the mean. The Reynolds shear-stress $(\tau)$ depends on the mean velocity fluctuation on two axes (e.g: $\bar{u}$, on $\mathrm{X}$ axes and $\bar{v}$, on $\mathrm{Y}$ axes) and the water density $(\rho)$ (White, 2004):

$$
\tau=\rho \cdot \overline{u^{\prime} \cdot \bar{v}^{\prime}}
$$

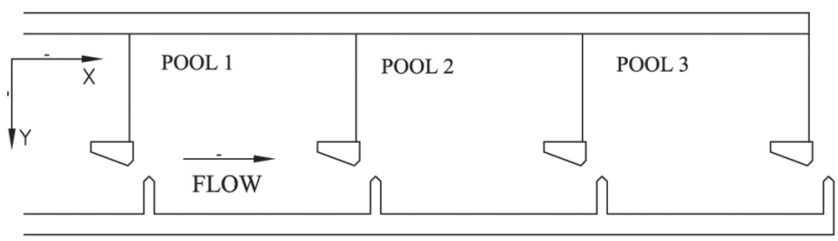

Fig.1. Scale model of vertical slot fish ladder. 
In this work, for each grid point, velocity fluctuations $(\bar{u})$ were not precisely sampled due to flow probe limitations. Alternatively, the mean fluctuation ( $\bar{u}$ '), which is ordinarily obtained by averaging a number of instantaneous velocity measurements, was replaced by the maximum velocity fluctuation value from about 80 data records of velocities (Fig. 2).

The maximum velocity fluctuations, on the $\mathrm{X}$ and $\mathrm{Y}$ axes were determined as per Eq. 2 and 3.

$$
\begin{aligned}
& u_{\text {max }}{ }^{\prime}=u_{\text {max }}-\bar{u} \\
& v_{\text {max }}{ }^{\prime}=v_{\text {max }}-\bar{v}
\end{aligned}
$$

where is the maximum velocity $(\mathrm{m} / \mathrm{s})$; is the mean velocity $(\mathrm{m} / \mathrm{s})$ on the $\mathrm{X}$ axis on each point; is the maximum velocity $(\mathrm{m} /$ $\mathrm{s})$; is the mean velocity $(\mathrm{m} / \mathrm{s})$ on the $\mathrm{Y}$ axis for each grid point. As the velocities were not measured in both dimensions simultaneously, the Reynolds shear-stress was obtained by a simplified approach.

In this work, flow was set for $20 \mathrm{~L} / \mathrm{s}$ to ensure that water velocity would not exceed swimming capacities from the fish species of study. Then, velocity measurements and fish experiments were taken under the discharge of $20 \mathrm{~L} / \mathrm{s}$. Flow was controlled by a magnetic flow meter located in the supply pipe.

Fish experiments were conducted after the hydraulic measurements. Adult fish individuals of $L$. reinhardti and $P$. maculatus were tested. These species occur in the São Francisco basin, which is the third biggest watershed in Brazil (Godinho, 1993).

Species of Leporinus are often abundant in fishways, sometimes with higher abundance than the large-sized migratory species (Santos et al., 2007) and individuals of $P$. maculatus are also very common in brazilian fishways (Santos et al., 2008). Although they show different strategies for negotiating swimming, the same fishway has been often built to mitigate impacts on both species.

Fish were captured at the Três Marias dam in Minas Gerais State (Brazil). Fish individuals were in the natural reproductive migration season, which generally takes place from November to April. Then, fish were placed in tanks equipped with aerator systems. In order to recover from transport and handling

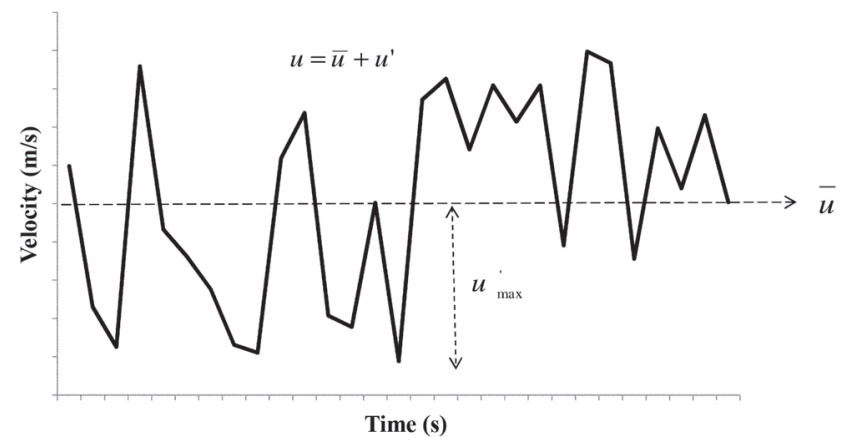

Fig.2. Graphic of components of local velocity. stress, fishes were kept in the tanks for at least one week before the experiments began.

All experiments were performed in the Hydraulic Laboratory of CEFET-MG. Each experiment lasted two hours. For the study of $L$. reinhardti behavior, five adult fishes were tested simultaneously during daylight period. The P. maculatus experiments were performed at night, due to nocturnal behavior of this species (Santos et al. 2008) with two individuals on each experiment. For the nighttime experiments, a red light was used to produce good contrast for film recordings. The difference between the numbers of individuals tested in each experiment is related to the difference in species sizes.

Each experiment started when individuals were introduced at the entrance of the fishway model, which is represented by pool 3. Experiments were conducted with five replicates for each species. Fish behavior was continuously monitored through the lateral glass window of the fishways and through the top of the flume by video recording system. Two digital video cameras were focused on the second pool. A reference grid, which was the same used for water velocity measurements, was painted on the flume bottom and on the opposite wall (Fig. 1), to determine the fish position and to connect the hydraulic data to fish experiment information.

After each experiment, total length, standard length and weight were collected and the individuals were transported to the maintenance system. Fish remained in laboratory no longer than seven days, when they were returned to river, in the same spot where the capture took place.

After the fish experiments, the video recordings were analyzed by frames, which were selected once every 2 minutes. In these analyses, the cells occupied by fish were determined for every 2 minutes and then the mode of occupied cell was calculated for each experiment. To obtain the preference of fish for a particular cell of the mesh, the hydraulic characteristics of that cell were calculated. In this study, preference was considered a statistical description of disproportionately high habitat use relative to a particular sample of the availability of that habitat (Beyer et al., 2010).

\section{Results}

The mean total length of tested fish was close to the values of first maturation size (Fig. 3): $12.9 \mathrm{~cm}$ for $L$. reinhardti (Rizzo et al., 1996) and $19 \mathrm{~cm}$ for P. maculatus (Santos et al., 2008). Based on the fish total lengths, the individuals used in experiments represent the appropriate sizes of fish attempting upstream passage, and results found for these species may be suitable for those fish populations.

Concerning the distribution of velocity in the second pool, L. reinhardti individuals remained in areas with low mean values, which were lower than $0.5 \mathrm{~m} / \mathrm{s}$ in close to $90 \%$ of the observations (Fig. 4). In figure 4, each arrow shows fish velocity preference in an experiment (each arrow represents an individual within a group). Arrow numbers indicate the number of experiments in which a fish displayed that value of preferred velocity. Individual $L$. reinhardti also showed a preference for 

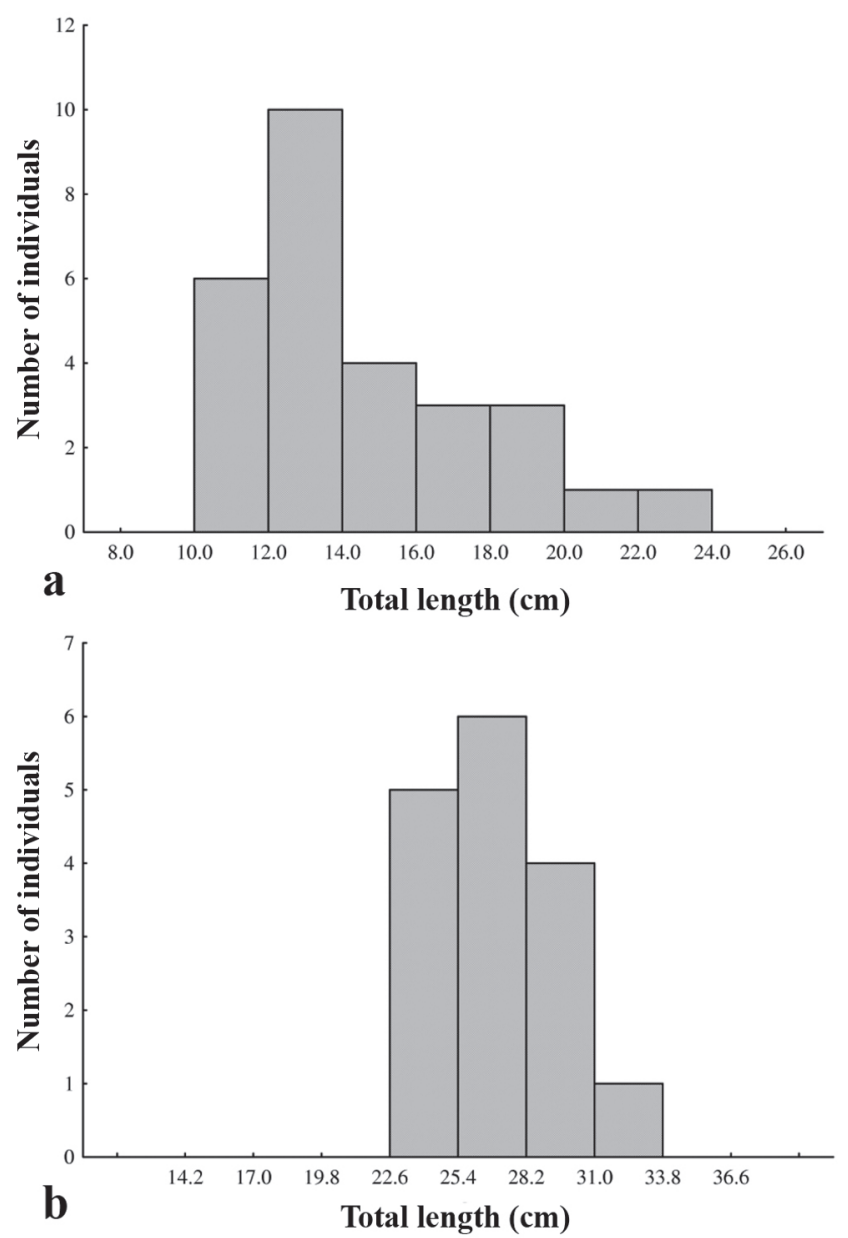

Fig. 3. The total length of tested fish a) Leporinus reinhardti; b) Pimelodus maculatus

high mean velocity areas, which were close to $0.8 \mathrm{~m} / \mathrm{s}$ during $10 \%$ of time observations. On the other hand, P. maculatus individuals remained in low mean velocity areas for $85 \%$ of the observations, which were not higher than $0.3 \mathrm{~m} / \mathrm{s}$.

Neither species displayed adequate passage from pool 3 (where fish were first placed in each experiment) to pool 2 (Fig. 5). Nevertheless, L. reinhardti individuals presented a higher mean success in passage than P. maculatus individuals. Although not statistically significant, a small difference of about 5\% may represent great results in these hydraulic structures, when considering the large numbers of fish ascending the fishway.

The second pool presented low values of Reynolds shearstress and velocity fluctuations on the $\mathrm{X}$ (horizontal) axis, namely close to 0 (zero) $\mathrm{Pa}$ and 0 (zero) $\mathrm{m} / \mathrm{s}$, respectively (Fig. 6 ). The most part of the flow areas may produce low values for these parameters, and fish avoided the limited areas where some higher values of these parameters exist.

Concerning the horizontal component of Reynolds shearstress and velocity fluctuations on the $\mathrm{X}$ axis, both species presented preferences for low values of these parameters. On

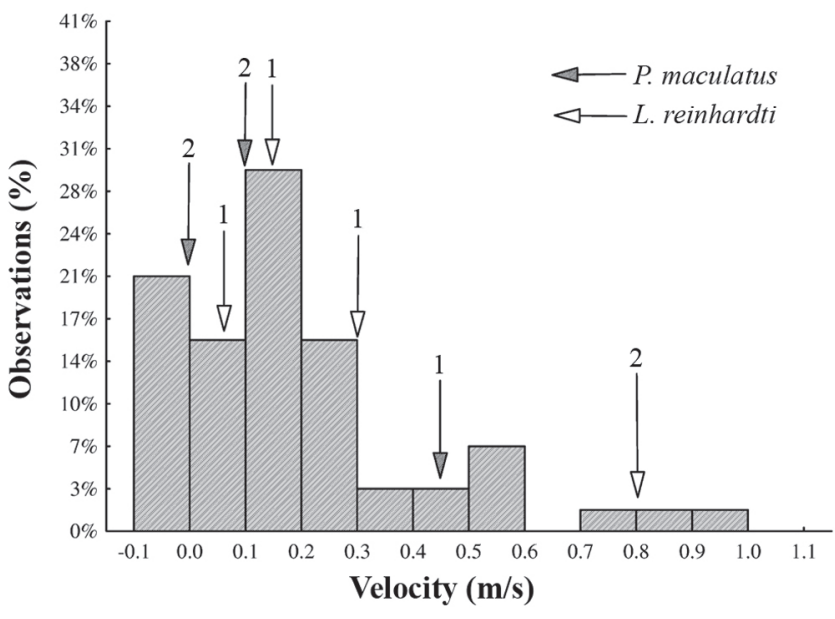

Fig. 4. The distribution of flow velocities in pool 2.

the other hand, only the individuals of $L$. reinhardti presented preferences for low velocity fluctuations on $\mathrm{Y}$ axis (Fig. 7). Then, individuals of $L$. reinhardti may prefer to swim in lower $Y$ axis fluctuations than individuals of $P$. maculatus.

Reynolds shear-stress may be presented as the main hydraulic parameters that positively influence fish behavior, when low values are present. (Table 1). Velocity fluctuation on the $\mathrm{X}$ and $\mathrm{Y}$ axes also may be considered as important factors, although the influence of turbulence may be fish species-specific.

\section{Discussion}

Understanding fish responses to environmental cues is critical to the development of effective fishways (Katopodis, 2005; Castro-Santos et al., 2009; Roscoe \& Hinch 2010).

Several hydraulic parameters are considered important for the success of fish migration. Particularly, turbulence has been

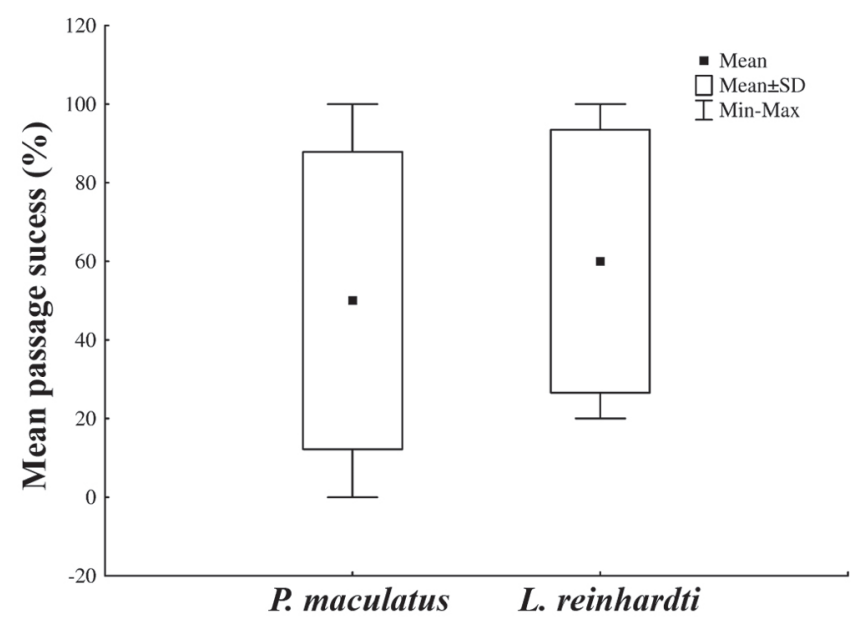

Fig. 5. Mean success passage from pool 2 to pool 3 for each species. 

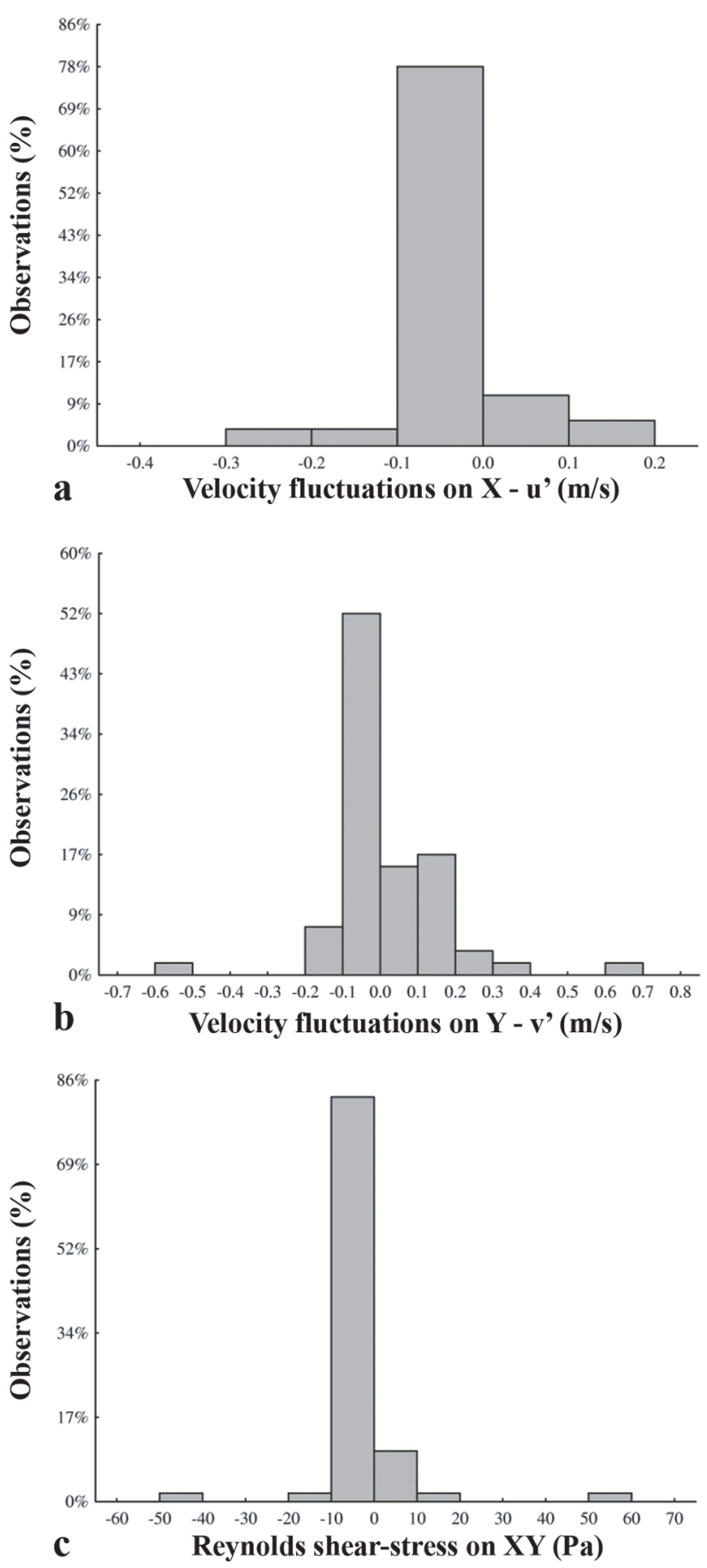

Fig. 6. The distribution of a) velocity fluctuation on $\mathrm{X}\left(u^{\prime}\right)$; $\left.\mathbf{b}\right)$ velocity fluctuation on $\mathrm{Y}\left(v^{\prime}\right)$; $\left.\mathbf{c}\right)$ Reynolds shear-stress on $\mathrm{XY}$; in pool 2.

tested in laboratory studies for fish movements (Hotchkiss, 2002; Odeh et al., 2002; Pavlov et al., 2000).

Low Reynolds shear-stress (close to $0 \mathrm{~Pa}$ ) areas were mainly preferred by $L$. reinhardti and P. maculatus, probably because it provides a more stable environment with lower

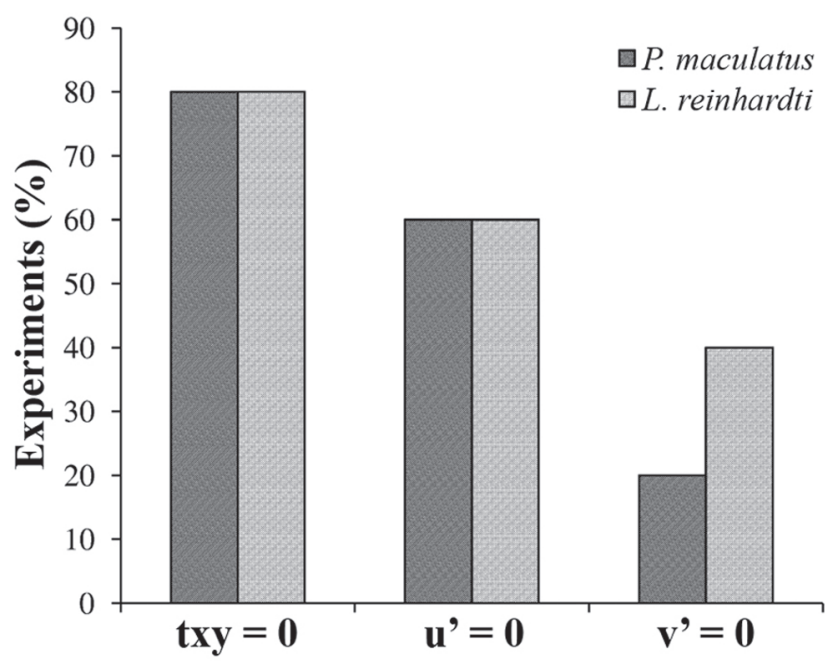

Fig. 7. The use (\%) of areas with null Reynolds shear-stress on $\mathrm{XY}$, null velocity fluctuation on $\mathrm{X}\left(u^{\prime}\right)$ and null velocity fluctuation on $\mathrm{Y}\left(v^{\prime}\right)$.

velocity gradient. High correlations between the horizontal component of Reynolds shear-stress and fish transit time, which means the time spent by the fish in a position in the pool, were found for Iberian barbel (Silva et al., 2010). Considering the availability of areas, both species that we tested showed preferences for null Reynolds shear-stress.

Other studies, as Silva et al. (2010), have applied high accurate flow probe for fishways analyses. Although the limitation of Reynolds shear-stress calculation in this work, this hydraulic parameter was important to explain the preference of neotropical fishes, which may not sense instantaneous turbulent flow fluctuations. If so, then the propeller velocity probe may provide an adequate picture of turbulence that fish experienced in the fishway.

Individuals of both species $L$. reinhardti and P. maculatus preferred areas of null turbulence $(80 \%$ of the time observations) and null velocity fluctuation on the horizontal (X) axis ( $60 \%$ of time observations). Concerning on velocity fluctuations on the $\mathrm{Y}$ axis $\left(v^{\prime}\right)$, P. maculatus individuals differed in their preferences from $L$. reinhardti individuals.

Table 1. Preferences for both species in Pool 2.Coloured cells represents different preference.

\begin{tabular}{ccccc}
\hline $\begin{array}{c}\text { Hydraulic } \\
\text { Parameter }\end{array}$ & $\begin{array}{c}\text { Availability } \\
(\%)\end{array}$ & Use (\%) & Preference & Species \\
\hline$\tau_{\mathrm{xy}}=0$ & 71 & 80 & 1.127 & P. maculatus / \\
$\tau_{\mathrm{xy}} \neq 0$ & 27 & 20 & 0.741 & L. reinhardti \\
\hline $\mathrm{u}^{\prime}=0$ & 59 & 60 & 1.017 & P. maculatus / \\
$\mathrm{u}^{\prime} \neq 0$ & 39 & 40 & 1.026 & L. reinhardti \\
\hline $\mathrm{v}^{\prime}=0$ & 36 & 20 & 0.556 & P. maculatus \\
$\mathrm{v}^{\prime} \neq 0$ & 63 & 80 & 1.270 & \\
\hline $\mathrm{v}^{\prime}=0$ & 36 & 40 & 1.111 & L. reinhardti \\
$\mathrm{v}^{\prime} \neq 0$ & 63 & 60 & 0.952 & \\
\hline
\end{tabular}


For $40 \%$ of the time observations, $L$. reinhardti individuals remained in null velocity fluctuations on $\mathrm{Y}\left(v^{\prime}\right)$, although individuals of $P$. maculatus were more tolerant of vertical velocity fluctuations, remaining in the null velocity fluctuations areas only $20 \%$ of the time.

The flow within the vertical slot fishway, depending on slope and slot configurations, produces two recirculation areas, with rotational movements (Wu et al., 1999). Observations of fish behavior indicated that small species may be trapped in the large recirculation zones and seem to have difficulty in rapidly passing through very large pools (Tarrade et al., 2008). The preference of P. maculatus not to swim in null fluctuations velocity on $\mathrm{Y}\left(v^{\prime}\right)$ areas may imply that the rotational movement plays important role in this fish species within the fish ladder. Then, the presence of two recirculation areas may explain the lower passage success of this species, when compared to observations of $L$. reinhardt $i$, and may also explain the presence of large numbers of $P$. maculatus in Brazilian fishways, which may have difficulty reaching the top of these fishways.

Water velocity is also an important parameter related to fish success in ascending a fishway, because velocity can affect movement through it (Fernandez et al., 2007). Facing velocity barriers, fish negotiate their passage in a region of lower flow velocities, or a region where velocities are within their swimming capability (Santos et al., 2007). In this experiment, individuals of $P$. maculatus remained in low mean velocity areas and avoided the main circulation area of flow within the fish ladder. On the other hand, individuals of $L$. reinhardti were occasionally found in higher mean velocity areas. Therefore, the two species appear to present different swimming strategies within this fishway type.

The preference of $L$. reinhardti for areas of higher velocity can also explain its highest success of passage. The preference of $P$. maculatus for areas of low velocity may indicate difficulties in progressing through the rotational flow of a vertical slot fishway. The swimming capacities of the two species tested are significant different. In Brazilian rivers, bottom dwelling species, such as P. maculatus, have lower swimming capacity than water-column species, such as $L$. reinhardti (Santos et al., 2007).

Fish may be attracted to swim in low Reynolds shearstress areas, even in which there are high mean velocities. Low Reynolds shear-stress areas may provide a less turbulent, less confusing environment which can be explored by the fish. The vertical slot fish ladder with the configuration used in this study may not be adequate for some neotropical species such as $P$. maculatus, because the fish might become disoriented due to the rotational flow patterns and then may not be able to find and reach the exit of the fish ladder.

Although fish react to many environmental variables, current velocity and its direction are dominant factors of fish movements. Reynolds shear-stress is an important parameter for behavior of neotropical fish species and should be considered a component in hydraulic criteria for future projects of fishways. However, each neotropical fish species has unique characteristics that may cause it to respond differently to hydraulic parameters such as components of velocity fluctuation characteristics. Because of the large diversity of neotropical fauna, understanding fish responses to hydraulic parameters is a challenge and requires specific studies for the target species. Therefore, the adoption of effective guidelines in fishway projects to allow the passage of neotropical ichthyofauna depends on detailed analyses of the swimming performance and behavior, according to the hydraulics parameters which have great biological response.

\section{Acknowledgments}

We are grateful to FAPEMIG and CNPq for financial support. Special thanks to Wescelau and Itamar, workers who helped us on the construction of experimental apparatus.

\section{Literature Cited}

Agostinho, C. S., A. A. Agostinho, F. Pelicice, D. A. de Almeida \& E. E. Marques. 2007. Selectivity of fish ladders: a bottleneck in Neotropical fish movement. Neotropical Ichthyology, 5: 205-213.

Beyer, H. L., D. T. Haydon, J. M. Morales, J. L. Frair, M. Hebblewhite, M. Mitchell \& J. Matthiopoulos. 2010. The interpretation of habitat preference metrics under use- availability designs. Philosophical Transactions of the Royal Society, 365: 2245-2254.

Castro-Santos, T., A. Cotel \& P. W. Webb. 2009. Fishway evaluations for better bioengineering: an integrative approach. In: Haro, A. J., K. L. Smith, R. A. Rulifson, C. M. Moffit, R. J. Klauda, M. J. Dadswell, R. A. Cunjak, J. E. Cooper, K. L. Beal $\&$ T. S. Avery. Challenges for Diadromous Fishes in a Dynamic Global Environment. Bethesda, MD: American Fisheries Society Symposium, 557-575.

Enders, E. C., D. Boisclair \& A. G. Roy. 2003. The effect of turbulence on the cost of swimming for juvenile Atlantic salmon (Salmo salar). Canadian Journal of Fisheries and Aquatic Sciences, 60: 1149-1160.

Fernandez, D. R., A. A. Agostinho, L. M. Bini \& L. C. Gomes. 2007. Environmental factors related to entry into and ascent of fish in the experimental ladder located close to Itaipu Dam. Neotropical Ichthyology, 5: 153-160.

Global Water Instrumentation. 2011. Global water products flowprobe. Available from: http://www.globalw.com/products/ flowprobe.html/ (23/08/12)

Godinho, A. L. 1993. E os peixes de Minas em 2010?. Ciência Hoje, 16: $44-49$

Godinho, H. P. \& A. L. Godinho. 1994. Ecology and conservation of fish in southeastern Brazilian river basins submitted to hydroelectric impoundments. Acta Limnologica Brasiliensia, 5:187-197.

Goodwin, R. A., J. M. Nestler, J. J. Anderson, L. J. Weber, \& D. P. Loucks. 2006. Forecasting 3-D fish movement behavior using a Eulerian-Lagrangian-agent method (ELAM). Ecological Modelling, 192: 197-223.

Hotchkiss, R., 2002. Turbulence investigation and reproduction for assisting downstream migrating juvenile salmonids. BPA Report DOE/BP-00004633-I, Bonneville Power administration, Portland, Oregon, 138p. 
Katopodis, C. 2005. Developing a toolkit for fish passage, ecological flow management and fish habitat works. Journal of Hydraulic Research, 43: 451-467.

Larinier, M. \& Murmulla, G. 2003. Fish passes: types, principles and geographical distribution : an overview. Second International Symposium on the Management of Large Rivers for Fisheries Sustaining Livelihoods and Biodiversity in the New Millennium. Phnom Penh, Cambodia, 183-205.

Lucas, M. C. \& E. Baras. 2001. Migration of Freshwater Fishes. Oxford, Blackwell Science, 420p.

Northcote, T. G. 1998. Migratory behavior of fish and its significance in movement through riverine passage facilities. Pp.113-123. In: Jungwirth, M., S. Schmutz \& S. Weiss. Migration and Fish Bypasses. Oxford: Fishing News Books, Blackwell Science.

Odeh, M., J. F. Noreika, A. Haro, A. Maynard, T. Castro-Santos \& G. F. Cada. 2002. Evaluation of the effects of turbulence on the behavior of migratory fish. Final Report 2002 to Bonneville Power Administration, Portland, OR, USA, 55p.

Pavlov, D. S., I. A. Lupandin \& M. A. Skorobogatov. 2000. The effects of flow turbulence on the behavior and distribution of fish. Journal of Ichthyology, 40: 232-261.

Pelicice, F.M. \& A. A. Agostinho Fish-Passage Facilities as Ecological Traps in Large Neotropical Rivers. Conservation Biology, 221: 180-188.

Petrere Jr., M. 1985. Migraciones de peces de agua dulce en America Latina: algunos comentarios. Copescal, Documento Ocasional, 1: $17 \mathrm{p}$.

Pon, L. B., S. G. Hinch, S. J. Cooke, D. A. Patterson \& A. P. Farrell. 2009. Physiological, energetic and behavioral correlates of successful fishway passage of adult sockeye salmon Oncorhynchus nerka in the Seton River, British Columbia. Journal of Fish Biology, 74: 1323-1336.

Rajaratnam, N., G. Van der Vinne \& C. Katopodis. 1986. Hydraulics of vertical slot fishways. Jounal of Hydraulic Engeneering, 112: 909-917.

Rizzo, E., Sato Y., Ferreira, R. M. A., Chiarini-Garcia, H. \& Bazzoli, N. 1996. Reproduction of Leporinus reinhardti (Pisces: Anostomidae) from the Três Marias Reservoir, São Francisco River, Minas Gerais, Brazil. Ciência e Cultura , 48: 189-192.

Roscoe, D. W. \& S. G. Hinch. 2010. Effectiveness monitoring of fish passage facilities: historical trends, geographic patterns and future directions. Fish and Fisheries, 11: 12-33.
Santos, H. A., P. S. Pompeu, C. B. Martinez. 2007. Swimming performance of the migratory Neotropical fish Leporinus reinhardti (Characiformes:Anostomidae). Neotropical Ichthyology, 5: 139-146.

Santos, H. A.; Pompeu, P. S.; Vicentini, G. S. \& Martinez, C. B. 2008. Swimming performance of the freshwater neotropical sh: Pimelodus maculatus Lacepède, 1803. Brazilian Journal of Biology, 68: 433-439.

Silva, A. T., M. T. Ferreira, A. N. Pinheiro \& C. Katopodis. 2010. Effects of water velocity and turbulence on the behavior of Iberian barbel (Luciobarbus bocagei, Steindachner 1864) in an experimental pool-type fishway. River Research and Applications, 27: 360-373.

Silva, A. T., J. M. Santos, A. C. Franco, M. T. Ferreira \& A. N. Pinheiro. 2009. Selection of Iberian barbel Barbus bocagei (Steindachner, 1864) for orifices and notches upon different hydraulic configurations in an experimental pool-type fishway. Journal of Applied Ichthyology, 25:173-177.

Tarrade, L., A. Texier, L. David \& M. Larinier. 2008. Topologies and measurements of turbulent flow in vertical slot fishways. Hydrobiologia, 609: 177-188.

Tarrade, L., G. Pineau, D. Calluaud, A. Texier, A. David \& M. Larinier. 2011. Detailed experimental study of hydrodynamic turbulent flows generated in vertical slot fishways. Environmental fluid mechanics, 11: 1-21.

Viana, E. M. F., M. T. C. Faria, C. B. Martinez. 2009. Levantamento das Curvas do Comportamento Hidráulico do Mecanismo de Transposição de Peixes da UHE de Igarapava. Revista Brasileira de Recursos Hídricos, 14: 113-122.

White, F. M. 2004. Mecânica dos Fluídos, 4 ed., Rio de Janeiro: McGraw-Hill, 570p.

Wu, S., N. Rajaratnam \& C. Katopodis. 1999. Structure of flow in vertical slot fishway. Journal of Hydraulic Engineering, 125: 351-360.

Yagci, O. 2010. Hydraulic aspects of pool-weir fishways as ecologically friendly water structure. Ecological Engineering, 36: 36-46.

Submitted March 15, 2012 Accepted October 15, 2012 